\title{
Interaction of long-term nitrogen fertilizer application, crop rotation, and tillage system on soil carbon and nitrogen dynamics
}

K.A. Congreves, D.C. Hooker, A. Hayes, E.A. Verhallen, and L.L. Van Eerd

This is a post-peer review, pre-copyedit version of an article published in Plant and Soil. The final authenticated version is available online at: https://doi.org/10.1007/s11104016-2986-y.

Suggested Citation: Congreves, K.A., Hooker, D.C., Hayes, A. et al. Interaction of long-term nitrogen fertilizer application, crop rotation, and tillage system on soil carbon and nitrogen dynamics. Plant Soil 410, 113-127 (2017). https://doi.org/10.1007/s11104016-2986-y 
K. A. Congreves ${ }^{\text {a }}$, D. C. Hooker ${ }^{\text {b }}$, A. Hayes ${ }^{\text {c }}$, E. A. Verhallen ${ }^{\text {c }}$, L. L. Van Eerd ${ }^{\text {a* }}$

Interaction of long-term nitrogen fertilizer application, crop rotation, and tillage system on soil carbon and nitrogen dynamics

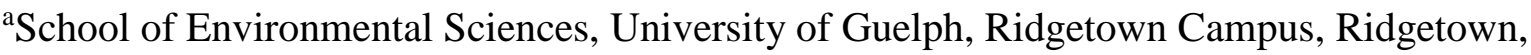 \\ Ontario, Canada N0P 2C0, 'Department of Plant Agriculture, University of Guelph, Ridgetown \\ Campus, Ridgetown, Ontario, Canada NOP 2C0, ${ }^{\mathrm{c}}$ Ontario Ministry of Agriculture, Food and \\ Rural Affairs, Ridgetown, Ontario, Canada NOP 2C0.
}

*Corresponding author: Telephone: 1-519-674-1500 x63644 Fax: 1-519-674-1640 email: lvaneerd@uoguelph.ca 


\title{
K. A. Congreves ${ }^{\text {a }}$, D. C. Hooker ${ }^{\text {b }}$, A. Hayes ${ }^{\text {c }}$, E. A. Verhallen ${ }^{\text {c }}$, L. L. Van Eerd ${ }^{\mathrm{a} *}$
}

\section{Interaction of long-term nitrogen fertilizer application, crop rotation, and tillage system on soil carbon and nitrogen dynamics}

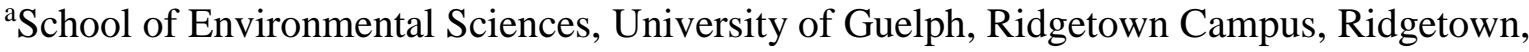 \\ Ontario, Canada NOP 2C0, bepartment of Plant Agriculture, University of Guelph, Ridgetown \\ Campus, Ridgetown, Ontario, Canada NOP 2C0, ${ }^{\mathrm{c}}$ Ontario Ministry of Agriculture, Food and \\ Rural Affairs, Ridgetown, Ontario, Canada NOP 2C0. \\ *Corresponding author: T: 1-519-674-1500 x63644 F: 1-519-674-1640 email:
} lvaneerd@uoguelph.ca

Keywords: continuous corn Zea mays; synthetic nitrogen fertilizer; moldboard plow/plough conventional tillage; no-till; soil organic matter; winter wheat Triticum aestivum

\begin{abstract}
Background and Aims Tillage system and crop rotation influences soil organic carbon (SOC) and total $\mathrm{N}(\mathrm{TN})$, but there remains considerable uncertainty in the response of $\mathrm{C}$ and $\mathrm{N}$ dynamics to fertilizer N inputs. A long-term (11-yr) experiment on a clay loam Orthic Humic Gleysol at Ridgetown, Ontario, Canada was used to evaluate the impact of fertilizer $\mathrm{N}$ applications (inseason zero $\mathrm{N}(-\mathrm{N})$ compared to $(+\mathrm{N}) 100$ and $80 \mathrm{~kg} \mathrm{~N} \mathrm{ha}^{-1} \mathrm{yr}^{-1}$ to corn (Zea mays L.) and wheat (Triticum aestivum L.), respectively) on soil attributes.
\end{abstract}


Methods The cropping systems consisted of continuous corn (CC), corn-soybean (Glycine max L.) (C-S) and corn-soybean-wheat (C-S-W) rotations using conventional moldboard plough and no-till systems. Soil was collected from the $0-120 \mathrm{~cm}$ profile in 5,10 , and $20 \mathrm{~cm}$ increments and analyzed for SOC and TN.

Results The effect and interaction of $\mathrm{N}$ fertilization on soil attributes was highly dependent on crop rotation and tillage system. The gain in SOC and $\mathrm{TN}$ contents due to $+\mathrm{N}$ fertilizer was greatest (up to 31 and $57 \%$ relative to the $-\mathrm{N}$ control, respectively) in the $0-20 \mathrm{~cm}$ depth with the C-S-W rotation, and lowest under CC, which showed no N fertilizer effect. However, differences in SOC and TN were not confined to the surface $20 \mathrm{~cm}$, as $\mathrm{N}$ fertilizer treatments significantly influenced the contents at 20-60 and 60-120 cm in certain rotation and tillage systems; C-S-W was the most responsive to $\mathrm{N}$ fertilizer-induced $\mathrm{SOC}$ and $\mathrm{TN}$ gains.

Conclusions Using regression analysis, we found that higher SOC contents corresponded to lower variability in the 5-yr mean corn yield, which suggests that the inclusion of winter wheat in a C-S rotation may have important implications for sustainable and resilient agroecosystems in humid, temperate climates.

Abbreviations: CC, continuous corn; C-S corn-soybean rotation; C-S-W, corn-soybean-wheat rotation; $-\mathrm{N}$, zero $\mathrm{N}$ treatment; $+\mathrm{N}$, fertilizer treatment; $\mathrm{SOC}$, soil organic carbon; $\mathrm{TN}$, total $\mathrm{N}$.

\section{Introduction}

Soils rich in organic matter are essential for sustainable food production and central to improving food security for the growing world population. In agriculture, synthetic $\mathrm{N}$ fertilizer applications are commonly relied upon for improving soil fertility and producing high crop 
yields, thus $\mathrm{N}$ fertilizer can be linked to sustaining a large portion of the human population (Smil, 1999; Galloway et al. 2003). As a consequence of N fertilization, soil organic C (SOC) and total N (TN) may increase due to greater inputs of crop residues (Gregorich et al. 1996), however, N fertilizer application can also stimulate organic matter mineralization leading to losses of $\mathrm{N}$ and SOC (Malhi and Lemke, 2007). Altering soil C and $\mathrm{N}$ turnover due to long-term $\mathrm{N}$ fertilizer applications could therefore result in enhanced or reduced soil fertility, which has important implications for society including development of sustainable agriculture, and the adaptability and resiliency of agriculture to climate change.

There are contrasting reports on the effects of long-term annual N applications on SOC and/or TN; with increased levels with N fertilization (Blevins et al. 1983; Havlin et al. 1990; Campbell et al. 2007). Others fount that SOC concentrations were not affected by $\mathrm{N}$ fertilization over 10 years, despite increased plant productivity at an alpine site in Colorado, USA (Neff et al. 2002). Long-term (135 yrs) fertilization at the Broadbalk experiment at Rothamsted increased soil TN and available $\mathrm{N}$ over time, but had no effect on soil microbial biomass $\mathrm{N}$ or SOC over time (Glendining et al. 1996). However, Blevins et al. (1983) and Havlin et al. (1990) found that >10 yrs of applying $\mathrm{N}$ fertilizer for corn production increased surface soil $\mathrm{C}$ levels in Kentucky and Kansas, USA. In continuous wheat cropping in Oklahoma with long-term annual fertilization (>90 $\mathrm{kg} \mathrm{N} \mathrm{ha}^{-1} \mathrm{yr}^{-1}$ for $23 \mathrm{yrs}$ ), SOC was unaffected compared to the no $\mathrm{N}$ fertilizer control (Raun et al. 1999). Therefore, the effects of long-term $\mathrm{N}$ fertilization on SOC have produced inconsistent results in the literature, and further research is needed for making informed decisions regarding sustainable crop rotation and tillage systems in corn, soybean, and wheat producing areas in the humid temperate climates such as Midwest USA and southeastern Canada. 
Although many studies have focused on SOC dynamics in the surface depths (i.e., 15 to 20 $\mathrm{cm}$ ) as influenced by management practices, processes underlying biogeochemical cycling at deeper depths are not well known or misunderstood, primarily due to the difficulty obtaining representative samples. Evidence indicates that management practices indeed influence SOC and/or TN levels in deeper soil depths (up to $100 \mathrm{~cm}$ ) (Gál et al. 2007; Varvel and Wilhelm, 2011; Van Eerd et al. 2014; Congreves et al. 2014a), therefore more research is needed to improve the understanding and characterization of how management influences deep soil nutrient dynamics.

Holistic, systems-based research, which integrates soil processes and crop production, is necessary for progress towards more sustainable agriculture. However, there is disconnect between soil and crop literature, with crop dynamics often being reported separately from soil processes. For example, at Ridgetown, Ontario the long-term impact of management on crop yields (Gaudin et al. 2015a) was reported separately from the impact on soil attributes (Van Eerd et al. 2014). Even within the soil science discipline, soil attributes which are intricately connected, such as soil N and C cycling (Havlin et al. 1990), have been studied independently, i.e., many studies have focused on how tillage systems or crop rotations affect SOC with little consideration on soil TN and/or inorganic N dynamics (Yang and Kay, 2001; Deen and Kataki, 2003; Campbell et al. 2000, 2007). Therefore, research which synthesizes treatment effects on SOC, TN, and crop productivity is essential in order to improve management strategies for longterm agriculture.

One long-term experiment of importance is located in Ridgetown, Ontario, Canada and initiated in 1995 on an Orthic Humic Gleysol where cropping systems with differing tillage, rotation, and fertility regimes have been studied (Van Eerd et al. 2014; Congreves et al. 2014a, 
2015a; Gaudin et al. 2015a, b). Soil data were collected 11-yr after establishment of an experiment at Ridgetown, Ontario with different tillage, crop rotation, and $\mathrm{N}$ fertilizer systems, with the following objectives: i) to determine the influence of $\mathrm{N}$ fertilizer on SOC, TN, C:N ratio, and soil bulk density in the $0-120 \mathrm{~cm}$ depth range, and ii) to assess the relationship between crop productivity and SOC and $\mathrm{TN}$. The Ridgetown study presents an important opportunity to couple the long-term soil and crop data, to further the ability to understand and quantify the interaction of management practices on crop productivity and soil attributes in a humid temperate climate.

\section{Materials and methods}

The experiment was established in 1995 at the University of Guelph Ridgetown Campus, Ridgetown, Ontario, Canada $\left(42^{\circ} 26^{\prime} \mathrm{N}, 81^{\circ} 53^{\prime} \mathrm{W}\right)$ on a clay loam soil. In the years prior to establishment of the experiment, the area produced winter wheat, soybeans, corn and alfalfa with a typical fertility program under conventional tillage and grain harvested. Treatments were established in a split-split plot design with four replications. Tillage system was the whole plot, crop rotation was the split plot, and $\mathrm{N}$ fertilizer treatment was the split-split-plot. Ridgetown is located in a humid, temperate climate, with a 30-yr average annual total precipitation of $895 \mathrm{~mm}$

$\mathrm{yr}^{-1}$ and a yearly average temperature of $9^{\circ} \mathrm{C}$. From May to September, the average total rainfall is $90 \mathrm{~mm} \mathrm{mo}^{-1}$ with average temperatures of 13.6 to $21.5^{\circ} \mathrm{C}$. More detailed climatic conditions are provided by Gaudin et al. (2015).

There were two tillage systems: conventional and no-till. For corn and soybean, the conventional tillage system consisted of moldboard plowing in the fall $(20 \mathrm{~cm}$ depth) followed by two to three passes with a field cultivator at $<10 \mathrm{~cm}$ depth in the spring. For winter wheat, 
conventional tillage consisted of two passes with either a tandem disc or cultivator after soybean harvest at $<8 \mathrm{~cm}$ depth. Crops in the no-till treatment had no tillage with minimal soil disturbance due to planting.

The crop rotations evaluated for this paper were: continuous corn (CC), corn-soybean (C-S) and corn-soybean-wheat (C-S-W). Crop rotations of two and three crops were duplicated and triplicated, respectively, so that all crops within each rotation were present in every year. The grain from each crop was mechanically harvested and crop residues returned each year.

No $\mathrm{N}$ fertilizer was applied to soybean. The split-split-plot treatment consisted of different $\mathrm{N}$ fertilizer rates applied to corn and wheat, plus a small amount of $\mathrm{N}\left(6\right.$ to $\left.12 \mathrm{~kg} \mathrm{~N} \mathrm{ha}^{-1}\right)$ applied at planting as a starter fertilizer. Each corn and wheat split-plot ( $6.1 \mathrm{~m}$ wide by $24 \mathrm{~m}$ long) was divided along the length into four $\mathrm{N}$ rate treatments applied in-season; however, soil sampling was performed on only two of the $\mathrm{N}$ treatments for this paper. The $\mathrm{N}$ fertilizer rate treatments were those applied through the planter vs. an additional 100 or $80 \mathrm{~kg} \mathrm{~N} \mathrm{ha}^{-1} \mathrm{yr}^{-1}$ to corn and wheat, respectively. At V3 developmental stage corn, urea ammonium nitrate (28-0-0) was injected at $10 \mathrm{~cm}$ deep in between rows and for winter wheat, urea (46-0-0) or ammonium nitrate (33-0-0) was broadcast applied at greenup. Hereafter, the $\mathrm{N}$ fertilizer treatments are differentiated by the abbreviation of $-\mathrm{N}$ (starter-N only) and $+\mathrm{N}$ (for the 100 or $80 \mathrm{~kg} \mathrm{~N} \mathrm{ha}^{-1}$ rates applied to corn and wheat, respectively). See Gaudin et al. (2015a) for more detail on fertilizer applications.

Crop management and soil sample collection and analysis have been previously described by Van Eerd et al. (2014). Briefly, soil samples were collected in November 2006 for SOC, TN, and soil bulk density determination from the corn phase of the crop rotations from three replicates. Due to unfavourable weather conditions, only two replicates from no-till CC and C-S were 
sampled. To create a composite soil sample, three to four intact 4-cm diameter cores from each plot collected to the $120 \mathrm{~cm}$ depth using a Giddings soil corer with tubes (Giddings Machine Company, Windsor, CO). Sampling occurred mid-way between non-wheel tracked crop rows, in the middle of each plot and at least $1 \mathrm{~m}$ from plot edges. Due to the lack of soil mixing during plowing and cultivating, it is likely that no-till soils exhibit higher spatial variability compared to conventional-tilled systems, thus four vs. three cores were taken in the no-till vs. conventional systems, respectively. As Van Eerd et al. (2014) described, individual cores were stored at $4^{\circ} \mathrm{C}$ until sectioned and soil bulk density was measured (Culley 1993) for each depth increment (5 cm increments from 0-20 cm, $10 \mathrm{~cm}$ increments from $20-60 \mathrm{~cm}, 20 \mathrm{~cm}$ increments from $60-120 \mathrm{~cm}$ depth). Cores from each plot were homogenized by depth increment, air dried, sieved ( $2 \mathrm{~mm})$, and analyzed for $\mathrm{C}$ and $\mathrm{N}$ concentration using automated combustion techniques, SOC corrected for carbonates content and SOC and TN expressed on an equivalent soil mass basis.

The five-year average grain corn yield from 2002 to 2006 was used to characterize relationships with production management practices and soil parameters. Additionally, to relate the SOC and TN measurements to crop residue inputs from 1995-2006, we estimated crop residue levels because actual crop residue measurements were not available. The DNDC model (Li et al. 1992) was used to estimate accumulated crop residue C quantities over the study period. Simulated crop residue levels generated by DNDC model were assumed reasonable because simulated crop yields had a 5.5\% of relative error of prediction with actual crop yield data from 1995-2006. Information on crop data collection and yields has been previously published, and readers are referred to Gaudin et al. (2015a) for a full description of the effects of tillage system, crop rotation, and $\mathrm{N}$ fertilizer on crop yields in 2009-2013.

Statistical analysis 
Statistical analyses were performed using SAS statistical software (Statistical Analysis System, version 9.3, SAS Institute, NC, USA). In all tests, a Type I error rate was set at 0.05 and analysis of variance was conducted using PROC MIXED. Residuals for soil attributes by replicate and $\mathrm{N}$ treatment were tested for homogeneity and normality using the Shapiro-Wilk W test $(\mathrm{P}>0.05)$. Analyses of variances were conducted for a split-split plot design when all three fixed effects were assessed (tillage system, crop rotation, and $\mathrm{N}$ fertilizer) using random effects of replication $\times$ tillage and replication $\times$ tillage $\times$ rotation. In some cases, data were further analyzed according to the split plot design as specified below.

When data were expressed as a change of 0-20 $\mathrm{cm} \mathrm{SOC}\left(\mathrm{MgC} \mathrm{ha}^{-1}\right)$ and TN $\left(\mathrm{Mg} \mathrm{N} \mathrm{ha}^{-1}\right)$ due to $\mathrm{N}$ fertilizer treatment, analysis of variance of crop rotation, tillage system, and depth were fixed, and the random effects were replication and replication $\times$ tillage. Analysis of variance was conducted for $0-120 \mathrm{~cm}$ soil attributes of SOC and $\mathrm{TN}\left(\%\right.$ and $\left.\mathrm{Mg} \mathrm{ha}^{-1}\right), \mathrm{C}: \mathrm{N}$ ratio, and bulk density, with fixed effects of crop rotation, tillage system, $\mathrm{N}$ fertilizer, soil depth, and respective interactions; while random effects were replication $\times$ tillage, and replication $\times$ tillage $\times$ rotation. If there were significant interactions, tillage systems were separated and analysis of variance using PROC MIXED was conducted with fixed effects of $\mathrm{N}$ fertilizer, rotation, depth, and respective interactions, and the random effects were replication and replication $\times$ rotation. Correlation and regression analyses were conducted using PROC CORR and PROC REG in SAS to identify the relationships among the measured 5-yr average corn yields from 2002-2006, crop management, and soil attributes. Only grain corn yield data were used (rather than soybean or wheat yields) for the regression analysis because soil samples were collected from the corn phase only. 


\section{Results}

Effects of $\mathrm{N}$ fertilizer on soil attributes in the $0-120 \mathrm{~cm}$ depth

For the soil C:N ratio, bulk density, SOC and TN (either expressed as concentration or content), the effect of $\mathrm{N}$ fertilizer depended on the tillage system and crop rotation, which caused a three-way interaction of $\mathrm{N}$ fertilizer $\times$ tillage $\times$ crop rotation (Table 1 ). Therefore, the $\mathrm{N}$ fertilizer effect was investigated within each rotation and tillage system separately. However, the effect of $\mathrm{N}$ fertilizer on the soil attributes did not interact with soil depth (Table 1), thus soil depth increments within the 0-120 cm range were pooled. Even when depth increments ranged from 5 to $20 \mathrm{~cm}$, pooling all depth increments was appropriate to analyze soil concentrations of SOC, TN, C:N ratio, and bulk density (Fig 1); however, when evaluating SOC and TN contents $\left(\mathrm{Mg} \mathrm{ha}^{-1}\right)$, only constant depth increments $(5,10$, or $20 \mathrm{~cm})$ were pooled for treatment contrasts.

Within the $0-120 \mathrm{~cm}$ profile, average bulk density was largely unaffected by $\mathrm{N}$ fertilization, except that $+\mathrm{N}$ fertilizer decreased bulk density by 0.3 and $0.1 \mathrm{~g} \mathrm{~cm}^{-3}$ in the conventionally tilled C-S-W and the no-till C-S rotation, respectively (Fig 1). Where significant differences were detected (Table 1), $+\mathrm{N}$ fertilizer treatments increased SOC and TN concentrations and decreased the soil C:N ratio (Fig 1). To reliably quantify management-induced changes in SOC and TN storage, methods must account for variations in soil mass in addition to SOC and TN concentration, soil bulk density, and soil thickness (Ellert and Bettany 1995). Hereafter the results are presented and discussed based on equivalent mass basis.

Soil organic $C$ and total $N$ contents: In the CC conventional tillage system, $\mathrm{N}$ fertilizer increased the content of SOC in deeper soil depths only $(60-120 \mathrm{~cm})$, and not in the surface 0-60 $\mathrm{cm}$ layers (Table 2). Due to $+\mathrm{N}$ fertilizer, $\mathrm{SOC}$ was increased by $18 \mathrm{Mg} \mathrm{C}^{-1}{ }^{-1}$ in the $60-120 \mathrm{~cm}$ 
profile (20 cm depth increments) and TN was increased by 1.1 to $2.6 \mathrm{Mg} \mathrm{N}^{-1}$ in the $20-60 \mathrm{~cm}$ and 60-120 cm depths based on 10 and $20 \mathrm{~cm}$ depth increments, respectively, in the $\mathrm{CC}$ conventional tillage system (Table 2).

In contrast to the conventionally tilled $\mathrm{CC}$ system, in the $\mathrm{CC}$ no-till system $\mathrm{N}$ fertilizer did not impact SOC and TN contents (Table 2). Thus, the effect of N fertilizer on increasing SOC and $\mathrm{TN}$ fertility under $\mathrm{CC}$ was determined by the tillage regime, emphasizing the importance of tillage systems on influencing subsurface SOC and TN dynamics.

In the tilled C-S-W system, long-term $+\mathrm{N}$ fertilizer applications significantly influenced contents for SOC with a similar but non-significant effect on soil TN (Table 2). In the tilled C-SW system, SOC was greater with $+\mathrm{N}$ compared to $-\mathrm{N}$ for the $0-20 \mathrm{~cm}$ depth by $10 \mathrm{Mg} \mathrm{Cha}^{-1}$ per $5 \mathrm{~cm}$ increment, by $12 \mathrm{Mg} \mathrm{Cha}^{-1}$ in the $20-60 \mathrm{~cm}$ depth per $10 \mathrm{~cm}$ increment, but not in the 60$120 \mathrm{~cm}$ range (Table 2). Interestingly, the $\mathrm{N}$ fertilizer effect on increasing 0-60 $\mathrm{cm}$ SOC content was unique to the tilled C-S-W rotation, compared to the tilled CC and C-S systems (Table 2). Thus, the combination of winter wheat cropping with $\mathrm{N}$ fertilizer applications had a positive impact on SOC sequestration (Table 2).

Similarly, in the no-till C-S-W rotation, due to $+\mathrm{N}$ fertilizer SOC and TN contents were increased by 5.4 $\mathrm{Mg} \mathrm{Cha}^{-1}$ and $3.0 \mathrm{Mg} \mathrm{N} \mathrm{ha}^{-1}$, respectively, in the top $20 \mathrm{~cm}$ depth $(5 \mathrm{~cm}$ increments). However, no differences between fertilizer treatments were observed in deeper soil layers for SOC, in contrast to conventional tillage system (Table 2). Thus, the distribution of the effect of N fertilizer on SOC and TN storage was dependent on the tillage system in C-S-W rotation.

There was no effect of $+\mathrm{N}$ fertilizer on SOC and TN content in the C-S rotation under conventional tillage system (Table 2). The only significant $+\mathrm{N}$ fertilizer effect in the no-till C-S 
system was $4 \mathrm{Mg} \mathrm{N} \mathrm{ha}^{-1}$ increase in $\mathrm{TN}$ at the 20 to $60 \mathrm{~cm}$ depth. Under no-till C-S, despite the lack of influence of $+\mathrm{N}$ fertilizer on SOC content (Table 2), $\mathrm{N}$ fertilizer input increased the TN content in the 20-60 cm depth (Table 2) and reduced the soil C:N ratio and bulk density (Fig 1) compared to the $-\mathrm{N}$ treatment. Overall, $\mathrm{N}$ fertilizer had a greater effect on soil attributes under no-till C-S than conventionally tilled C-S, a trend which contrasts with that found in the CC system. Thus, the effect and interaction of $\mathrm{N}$ fertilization and tillage system on soil attributes was highly dependent on the crop rotation.

Change in SOC or TN content due to $\mathrm{N}$ fertilizer in the surface $0-20 \mathrm{~cm}$ depth

The effect of $+\mathrm{N}$ fertilizer on the change in SOC and TN content $\left(\mathrm{Mg} \mathrm{ha}^{-1}\right)$ in the top $20 \mathrm{~cm}$ profile was expressed as a percentage of the $-\mathrm{N}$ fertilizer control treatment. The $5 \mathrm{~cm}$ depth increments from the $0-20 \mathrm{~cm}$ profile were pooled to investigate the crop rotation effects, based on the non-significant rotation $\times$ depth interaction (Table 4). Due to $\mathrm{N}$ fertilizer, there was a significant crop rotation $\times$ tillage effect on the change in SOC content $(\mathrm{P}=0.0072)$, but not for $\mathrm{TN}$ content ( $\mathrm{P}=0.1084)$ (Table 4). Thus, within the $0-20 \mathrm{~cm}$ depth to investigate the rotation effect, tillage systems were separated for SOC content change, but pooled to quantify the TN content change due to $\mathrm{N}$ fertilizer.

Overall, the effect of $\mathrm{N}$ fertilizer on the change in SOC and TN content in the 0-20 cm depth was greatest (up to 31 and 57\%, respectively) with winter wheat in crop rotation, and lowest under $\mathrm{CC}$, which showed no $\mathrm{N}$ fertilizer effect (Fig 2). For the C-S-W rotation, SOC content in the $0-20 \mathrm{~cm}$ depth increased due to $\mathrm{N}$ fertilizer treatment regardless of tillage system (Fig 2). The relative change in SOC content in the $0-20 \mathrm{~cm}$ depth due to $\mathrm{N}$ fertilization in the C-S system was different depending on the tillage system with gains of $23 \%$ observed in the no-till system only, 
while in $\mathrm{CC}$ the tillage system did not influence the effect of $\mathrm{N}$ fertilizer on $0-20 \mathrm{~cm} \mathrm{SOC}$ or TN content gain/loss (Fig 2, 3). For soil TN content in the $0-20 \mathrm{~cm}$ depth, $+\mathrm{N}$ treatments resulted in a gain of 38 to $57 \%$ relative to the $-\mathrm{N}$ control for the $\mathrm{C}-\mathrm{S}$ and $\mathrm{C}-\mathrm{S}-\mathrm{W}$ rotations respectively, which was significantly greater than the CC system (Fig 3).

Notably, differences between $\mathrm{N}$ fertilizer treatments were not solely confined to the surface $20 \mathrm{~cm}$, as $\mathrm{N}$ fertilizer treatments significantly influenced the $20-60 \mathrm{~cm}$ and $60-120 \mathrm{~cm}$ levels of SOC and TN for certain rotation/tillage combinations, as described in the following section.

Relationship between soil organic $\mathrm{C}$ and total $\mathrm{N}$ content with crop productivity

Overall, including winter wheat in the rotation had the greatest gains in SOC and TN due to $+\mathrm{N}$ fertilizer (Fig 2, 3); SOC and TN content levels were most responsive to $+\mathrm{N}$ fertilization (Table 2). While greater quantities of crop residue $\mathrm{C}$ were contributed to the soil after harvest in the $+\mathrm{N}$ systems compared to the $-\mathrm{N}$ controls, of the $+\mathrm{N}$ fertilizer treatments the $\mathrm{C}-\mathrm{S}-\mathrm{W}$ rotation was predicted to have had the lowest levels of accumulated crop residue inputs (Table 3).

Corn yield variability was inversely correlated to SOC levels in the 0-20 cm depth (Fig 4). Thus, our regression analysis links higher SOC with lower variability in yield. However, no clear relationship was found between average corn yields and SOC and TN contents in the 0-20 cm depth, nor soil TN content and crop productivity (Fig 4).

\section{Discussion}

Effects of $\mathrm{N}$ fertilizer on soil attributes

The aim of this paper was to evaluate the influence of long-term $\mathrm{N}$ fertilization on soil $\mathrm{C}$ and $\mathrm{N}$ stores as influenced by crop rotation and tillage systems. In a recent review, Stockmann et al. 
(2013) estimate a rate of net accumulation of $0.2-0.3 \mathrm{t} \mathrm{C} \mathrm{ha}^{-1} \mathrm{yr}^{-1}$ as a result of nutrient management in a humid, temperate climate which was primarily attributed to crop residue $\mathrm{C}$ inputs. However, our research shows the long-term impact of $\mathrm{N}$ fertilization on SOC accumulation was dependent on the crop rotation and the tillage system.

Previous some studies have shown increased levels of SOC after $>10$ yrs of annual N applications (Blevins et al. 1983; Havlin et al. 1990; Campbell et al. 2007), while others have found little or no difference in SOC concentrations between control and N fertilized plots (Raun et al. 1999; Glendining et al. 1996; Neff et al. 2002; Blanco-Canqui et al. 2014). Our results support both patterns as $\mathrm{N}$ fertilizer-induced soil attribute responses were dependent on crop rotation and tillage system. The discrepancies regarding the response of SOC to long-term N fertilization may be related to differences in crop productivity and management, because practices such as tillage, cropping frequency, and/or crop rotation influence soil C dynamics (Janzen et al. 1998; West and Post, 2002; Van Eerd et al. 2014; Congreves et al. 2014a). The interaction of $\mathrm{N}$ fertilization with crop rotation and tillage systems is evidence that the role of $\mathrm{N}$ fertilization on SOC cannot be generalized across different agricultural systems. In the tilled C$\mathrm{S}-\mathrm{W}$ system, SOC was greater with $+\mathrm{N}$ compared to $-\mathrm{N}$ in the top two depths, but not in the 60$120 \mathrm{~cm}$ range (Table 2). Likewise, in the no-till C-S-W rotation, SOC and TN contents were higher with $\mathrm{N}$ fertilizer in the top $20 \mathrm{~cm}$ depth only. Thus, the distribution of the effect of $\mathrm{N}$ fertilizer on SOC and TN storage was dependent on the tillage system in C-S-W rotation. The combination of winter wheat cropping with $\mathrm{N}$ fertilizer applications may have had a positive impact on SOC sequestration, as a $\mathrm{N}$ fertilizer effect was not observed consistently with tillage treatments in the CC and C-S systems (Table 2). 
Data from $-\mathrm{N}$ and $+\mathrm{N}$ treatments corroborate earlier results published from this same Ridgetown site, which showed that including winter wheat in crop rotation increased overall soil health (Congreves et al. 2015a), soil C and N storage (Van Eerd et al. 2014), corn and soybean crop yields and $\mathrm{N}$ use efficiency (Gaudin et al. 2015a). The $\mathrm{C}-\mathrm{S}-\mathrm{W}$ rotation was unique such that $\mathrm{N}$ fertilizer increased SOC and TN under both tillage systems, and tillage influenced the distribution of the effect. Consequently, the effect of winter wheat on SOC and soil N storage may play a key role in improving resiliency to environmental stress and minimizing $\mathrm{N}$ inputs in humid continental climates in the temperate zone such as the Northern Corn Belt.

There are few other long-term $\mathrm{N}$ fertilizer studies that allow for direct comparisons with winter wheat in the rotation in different tillage systems. In a four-yr rotation (winter wheat, clover/grass forage, spring barley, turnips (or beets)) in Denmark, compared to the unfertilized control, there was a $1.2 \mathrm{~g} \mathrm{~kg}^{-1}$ increase in SOC due to $\mathrm{N}$ fertilizer applied at an equivalent rate of $100 \mathrm{~kg} \mathrm{~N} \mathrm{ha}^{-1} \mathrm{yr}^{-1}$ for $90 \mathrm{yrs}$ in the $0-20 \mathrm{~cm}$ layer, but no difference in the $30-35 \mathrm{~cm}$ depth (Schjønning et al. 1994). In addition to climatic differences, the contrasting lack of $\mathrm{N}$ fertilizer effect at depth observed by Schjønning et al. (1994) may be due to the lighter sandy loam soil compared to clay loam in our study, as clay holds more SOC. Accordingly, it is not merely crop diversity driving SOC storage.

In the tilled $\mathrm{CC}$ system, our results indicate that long-term $\mathrm{N}$ fertilizer inputs contributed to SOC and TN storage, and demonstrate the importance of soil layers below the plough layer (> 20 $\mathrm{cm}$ ) in sequestering $\mathrm{C}$ and N, consistent with findings by Van Eerd et al. (2014) and Gál et al. (2007). In contrast to the conventionally tilled CC system, N fertilizer did not impact SOC and TN contents in the CC no-till system (Table 2). The placement of the residues - whether left on the soil surface (where they dry and are exposed) or incorporated (where they are exposed to 
high humidity and in close proximity to biota) - had an effect on residue decay and potential SOC accumulation, but the impact of $\mathrm{N}$ fertilization was not consistent with tillage management. Similar to our study, a tillage by $\mathrm{N}$ fertilization interaction was observed by Mazzoncini et al. (2011) in a Mediterranean climate; the interaction was only observed with SOC in the $0-10 \mathrm{~cm}$ but not to the measured $30 \mathrm{~cm}$ depth. Likewise, after 11-yr of CC in a humid, temperate climate, differences in tillage management influenced SOC and TN pools (Halpern et al. 2010). Our findings agree with the study by Gregorich et al. (1996) where N inputs increased SOC storage in $\mathrm{CC}$ systems, rather than $\mathrm{N}$ fertilizer applications stimulating organic matter mineralization and promoting losses of SOC or TN. Thus $\mathrm{N}$ fertilizer was important to maintain SOC and TN in the tilled CC system, which may correspond to improved yield stability (Fig 4) in years with excess or deficit soil moisture (Gaudin et al. 2015b) likely due to improved soil functioning such as water holding capacity, aggregate stability, penetrometer resistance (Van Eerd et al. 2014). The influence of SOC on crop productivity is discussed further in the subsequent section.

Under no-till C-S, despite the lack of influence of $+\mathrm{N}$ fertilizer on SOC content (Table 2), N fertilizer input increased the TN content in the 20-60 cm depth (Table 2), and reduced the soil C:N ratio and bulk density (Fig 1) compared to the $-\mathrm{N}$ treatment. Overall, $\mathrm{N}$ fertilizer had a greater effect on soil attributes (Fig 1) and the change in SOC (Fig 2) under no-till C-S than conventionally tilled C-S, a trend which contrasts with that found in the CC system. Thus, the effect and interaction of $\mathrm{N}$ fertilization and tillage system on soil attributes was highly dependent on the crop rotation. While Gál et al. (2007) found few differences in SOC and TN dynamics under CC compared to C-S rotations, our results have shown otherwise. Similar to our observations, McVay et al. (2006) found no-till had higher SOC than conventional or reduced tillage systems, but in contrast to our results, they observed no effect of $\mathrm{N}$ fertility ( $0 \mathrm{vs} .140 \mathrm{~kg}$ 
$\mathrm{N} \mathrm{ha}^{-1}$ ) in a grain sorghum-soybean rotation from a 20-yr long-term trial under a wet temperate climate (precipitation $1070 \mathrm{~mm} \mathrm{yr}^{-1}$ ). However, in sites with less precipitation (470 to $870 \mathrm{~mm}$ $\left.\mathrm{yr}^{-1}\right) \mathrm{N}$ fertilizer inputs increased SOC content in the 0-5 cm depth with no impact at lower depths (McVay et al. 2006), therefore emphasizing the influence of climate on $\mathrm{C}$ and $\mathrm{N}$ stores. With a difference of only $31 \%$ in $\mathrm{N}$ fertilization rate, after $13 \mathrm{yrs} \mathrm{N}$ but not $\mathrm{C}$ stores deceased at a rate of $7.3 \mathrm{~kg} \mathrm{~N} \mathrm{ha}^{-1} \mathrm{yr}^{-1}$ in a conventional tillage system (Constantin et al. 2010). This decrease in $\mathrm{N}$ stores was attributed to lower crop productivity and lower residue inputs with the lower $\mathrm{N}$ rate treatment. In contrast to Constantin et al. (2010), in our study there was no reduction in SOC or TN content (Fig 2 and 3) due to $\mathrm{N}$ treatment in any crop rotation or tillage systems tested.

Numerous studies have shown soil C storage is strongly related to the quantity of net $\mathrm{C}$ returned to the soil from crop residues (Rasmussen et al. 1980; Havlin et al. 1990; Campbell et al. 2000; Congreves et al. 2015b). For instance and similar to our results (Table 3), Studdert and Echeverria (2000) concluded that higher frequencies of soybean in crop rotations corresponded to lower SOC contents, due to its relatively low amount and highly decomposable above-ground crop biomass and $\mathrm{C}$ inputs. While greater quantities of crop residue $\mathrm{C}$ were returned to the soil after harvest in the $+\mathrm{N}$ systems compared to the $-\mathrm{N}$ controls, of the $+\mathrm{N}$ fertilizer treatments, the C-S-W rotation was predicted to have had the lowest levels of accumulated crop residue inputs (Table 3). Thus, the quantity of crop residue $\mathrm{C}$ input was likely not the main factor in explaining our SOC and TN results. Plant species composition, quality of crop residues (Drinkwater et al. 1998) and soil $\mathrm{N}$ availability (Diochon et al. 2016) likely had more significant impacts on C storage in our study. Elsewhere, the decline in SOC and TN observed in a moldboard plow tillage system without $\mathrm{N}$ input for 18 years could not be merely accredited to crop rotation (CC, 
C-S and continuous soybean), low crop residue quantities and/or increased decomposition (Diochon et al. 2016). Therefore, understanding and quantifying the interaction between crop rotation, tillage, and $\mathrm{N}$ fertilizer treatments on SOC is essential for maintaining or enhancing crop productivity. Generally, the potential impact of long-term cropping with vs. without $\mathrm{N}$ fertilization to enhance crop residue decomposition is outweighed by the increase in crop residues left in the field due to higher productivity with $\mathrm{N}$ fertilization (Powlson et al. 2010). Overall, the $\mathrm{N}$ fertilizer treatment in our 11-yr experiment likely did not directly alter the dynamics of soil organic matter in terms of a direct effect of $\mathrm{N}$ fertilization on 1) SOC or TN levels, 2) the efficiency of conversion of plant residue inputs to SOM, nor 3) enhanced decomposition of crop residues. The interaction of crop rotation and tillage system with the observed $\mathrm{N}$ fertilization treatment differences can be attributed to quantities and chemical composition of crop residue being added annually, which in-turn influenced SOC and TN. Consequently, it is not simply crop diversity but the resulting quantity and quality of $\mathrm{C}$ inputs that may be driving SOC storage.

In contrast to our results, many of the aforementioned studies did not observe a $\mathrm{N}$ fertilizer effect on SOC or TN below $30 \mathrm{~cm}$. Mulvaney et al. (2009) observed declining subsurface soil C and $\mathrm{N}$ stores (15-30 and 30-46 cm depths), which was greater when manure was replaced with synthetic fertilizer. This observed decline was in contrast to Jenkinson et al. (2008) where there was no evidence of a $\mathrm{N}$ fertilizer effect on $\mathrm{C}$ or $\mathrm{N}$ stores with depth. Despite a lack of management effect on SOC or TN in the subsoil layers observed by many studies, others have suggested a need to study subsoil C and N stores (Mulvaney et al. 2009; Olson et al. 2014). For instance, in addition to our present study, research by Angers et al. (1997), Gál et al. (2007), and Van Eerd et al. (2014) have shown that tillage (i.e., fall/spring moldboard ploughing) altered 
deep (up to 40, 50, or $100 \mathrm{~cm}$ ) SOC and TN dynamics compared to no- and minimal-tillage systems. Although the mechanism of SOC and TN accumulation in deeper $(60-120 \mathrm{~cm})$ soil depths is not known, it cannot solely be explained by $\mathrm{N}$ fertilizer inputs or crop residue inputs; hence, future research should explore possible explanations. Our results support the importance of how tillage influences the distribution of dissolved organic matter, root biomass and physically or biologically transported particulate organic matter, as these are considered the main sources of subsurface soil organic matter (Rumpel and Kögel-Knabner, 2011). Similarly, dissolved organic $\mathrm{C}$ levels in soils were found dependent on tillage due to the influence on residue placement (Wright et al. 2007). Clearly, there is a need to better understand the influence of below-ground plant inputs on C and N dynamics (Stockmann et al. 2013).

Relationship between soil organic $\mathrm{C}$ and total $\mathrm{N}$ with crop productivity

A recent global meta-analysis demonstrated that by combining two or more 'conservation management practices' (such as diverse crop rotations, residue retention, and no-till), negative impacts on crop yields can be reduced (Pittelkow et al. 2015). Similarly, our results indicate that adding winter wheat to a no-till system helped to negate any negative effects of no-till on corn yield, which is applicable to other humid continental climates in the temperate zone. The highest corn and soybean yields and the most stable yields over-time were observed with winter wheat in crop rotation, while the lower yields and higher yield variability were observed in continuous corn and corn-soybean rotations (Gaudin et al. 2015b); however, it was not previously reported how soil characteristics contributed to average yields and yield stability, so we present the first paper to integrate crop productivity data with soil attribute data. Our study demonstrates the potential for improving yield stability by increasing SOC content (Fig 4), and because winter 
wheat contributed to greater gains in SOC (Fig 2) it supports the conclusions of the previous work that winter wheat contributes to improved yield stability (Gaudin et al. 2015b), improved soil health (Congreves et al. 2015a), and SOC and TN sequestration (Van Eerd et al. 2014).

While long-term diverse cropping may indeed contribute to improving soil attributes, we suggest that crop species (i.e., winter wheat) and the resulting quantity and quality of $\mathrm{C}$ inputs may be more important than total cropping diversity for enhancing soil SOC and TN sequestration. The quantity of crop residue $\mathrm{C}$ input due to $\mathrm{N}$ fertilization was not the main factor in explaining our SOC and TN results and crop species, which was similar to (Blanco-Canqui et al. 2014). As such, the quality of crop residues likely had a greater influence on long-term soil organic matter turnover (Drinkwater et al. 1998). Further, roots and below-ground residue have contributed more to organic and relatively stable $\mathrm{C}$ and $\mathrm{N}$ pools than above-ground crop residue (Kätterer at al., 2008; Arcand et al. 2014; Congreves et al. 2014b). This may favour crop rotations with species that have high below-ground C inputs (Stockmann et al. 2013), and partially explains our observed effects of winter wheat in the rotation.

The mechanism of SOC accumulation with winter wheat is not known but may be related to quantity and composition of lignin (Broder and Wagner 1988), and can therefore take longer to decompose than corn or soybean. However, long-term $\mathrm{N}$ fertilization can enhance lignin oxidation and accumulation of microbial-derived components in soil (Pisani et al. 2015), which may help explain why SOC and TN levels were most responsive to $+\mathrm{N}$ fertilization by including winter wheat in crop rotation in our study. Considering the contribution of microbial C inputs may be underestimated using traditional methods (Simpson et al. 2007) and the influence of $\mathrm{N}$ fertilization in grasslands on decreased decomposition mediated by reduced microbial biomass (Riggs and Hobbie 2016), a synergistic effect of winter wheat and $\mathrm{N}$ fertilization on soil 
microbial dynamics could contribute to explaining our results. Future research should focus on the underlying mechanism that may explain the benefit of crop diversity and specifically of winter wheat on $\mathrm{C}$ and $\mathrm{N}$ dynamics.

\section{Conclusions}

Changes in SOC and TN storage due to $\mathrm{N}$ fertilizer application were highly dependent on tillage system and the crop rotation. Nitrogen fertilizer had more effects on 0-120 $\mathrm{cm} \mathrm{SOC}$ and TN storage under no-till than conventional tillage systems for the C-S rotation, but the opposite was true for CC production. In the C-S-W rotation, $\mathrm{N}$ fertilizer increased SOC and TN contents in both tillage systems and tillage system influenced the distribution of the effect. The surface $(0-$ $20 \mathrm{~cm}) \mathrm{SOC}$ and TN levels were more associated with crop rotation while deeper $(60-120 \mathrm{~cm})$ SOC and TN dynamics were more related with the type of tillage system. While subsurface (i.e., below $60 \mathrm{~cm}$ soil depths) $\mathrm{C}$ and $\mathrm{N}$ dynamics have typically yielded no management treatment effects, our study suggests that subsurface SOC and TN are more dynamic than previously detected and thereby has important consequences for developing and improving agroecosystem models to better simulate soil $\mathrm{C}$ and $\mathrm{N}$ sequestration dynamics. Therefore, our findings contribute to the knowledge and understanding of the spatial and temporal dynamics of SOC and TN, demonstrates the importance of sampling deep soil profile layers (up to $120 \mathrm{~cm}$ ) and have important implications for informing precision agriculture ventures by recommending soil sampling beyond the typical $15 \mathrm{~cm}$ or $30 \mathrm{~cm}$ depths.

We document how agricultural practices of tillage system, crop rotation, and $\mathrm{N}$ fertilizer interact to influence soil attributes within a deep soil profile (> $1 \mathrm{~m}$ ), using a long-term study. Although the impact of $\mathrm{N}$ fertilization on soil attributes was highly dependent on crop rotation 
and tillage system employed, the positive influence of winter wheat in the crop rotation under both tillage systems was evident. After $11 \mathrm{yr}, \mathrm{N}$ fertilizer treatment did not consistently increase SOC or TN despite differences in crop productivity and C input; hence the blanket statements that $\mathrm{N}$ fertilizer is needed to maintain SOC content needs to be refined to specific production system practices. Our observed results may be due to the length of the study (11yr) or the relatively modest $\mathrm{N}$ fertilizer rates tested (80 to $100 \mathrm{~kg} \mathrm{~N} \mathrm{ha}^{-1}$ to winter wheat and corn, respectively); hence, we are unsure of the implications of longer time periods or higher $\mathrm{N}$ applications, such as those typically used in commercial corn production in North America.

While previous research has demonstrated that including winter wheat in crop rotations increased corn and soybean yields, corn $\mathrm{N}$ use efficiency, improved corn and soybean yield stability (Gaudin et al. 2015a, b), and increased general soil health (Congreves et al. 2015a), SOC and TN levels (Van Eerd et al. 2014), we present the first study to integrate soil and crop

yield data to show that winter wheat contributed to greater gains in SOC in both tillage systems, and higher SOC levels corresponded to lower crop yield variability. By including winter wheat into corn-based rotations, SOC and TN storage may increase, which corresponds to improving yield stability and agroecosystem resiliency to environmental stresses. This has important implications for maintaining high crop productivity and the competitiveness of agriculture in humid temperate climates.

\section{Acknowledgements}

Authors acknowledge past and present researchers for establishing and maintaining the longterm trial at the University of Guelph Ridgetown Campus, especially Doug Young, and Scott Jay, as well as Dr. R. P. Beyaert for SOC and TN analysis. We thank the following funding 
sources: Grain Farmers of Ontario, Ontario Ministry of Agriculture, Food and Rural Affairs, Agricultural Adaptation Council, and Agriculture and Agri-Food Canada’s Greenhouse Gas Mitigation Program.

\section{References}

Angers, D., Bolinder, M., Carter, M., Gregorich, E., Drury, C., Liang, B., Voroney, R. P., Simard, R., Donald, R. and Beyaert, R. 1997. Impact of tillage practices on organic carbon and nitrogen storage in cool, humid soils of eastern Canada. Soil Tillage Res. 41: 191-201.

Arcand, M M, Diane Knight J D and Farrell R E (2014) Differentiating between the supply of N to wheat from above and belowground residues of preceding crops of pea and canola. Biol Fertil Soils 50:563-570.

Blanco-Canqui H, Ferguson R B, Shapiro C A, Drijber R A and Walters D T (2014) Does inorganic nitrogen fertilization improve soil aggregation? Insights from two long-term tillage experiments. J. Environ. Qual. 43:995-1003

Blevins R L, Thomas G W, Smith M S, Frye W W and Cornelius P L (1983) Changes in soil properties after 10 years continuous non-tilled and conventionally tilled corn. Soil Tillage Res. 3:135-146

Broder M W and Wagner G H (1988) Microbial colonization and decomposition of corn, wheat, and soybean residue. Soil Sci. Soc. Am. J. 52:112-117

Campbell C A, VandenBygaart A J, Grant B, Zentner R P, McConkey B G, Lemke R, Gregorich E G and Fernandez M (2007) Quantifying carbon sequestration in a conventionally tilled crop rotation study in southwestern Saskatchewan. Can. J. Soil Sci. 87:23-38 
Campbell C A, Zentner R P, Liang B C, Roloff G, Gregorich E C and Blomert B (2000) Organic $\mathrm{C}$ accumulation in soil over 30 years in semiarid southwestern Saskatchewan-Effect of crop rotations and fertilizers. Can. J. Soil Sci. 80:179-192

Congreves K A, Smith J M, Nemeth D D, Hooker D C and Van Eerd L L (2014a) Soil organic carbon and land use: Processes and potential in Ontario's long-term agro-ecosystem research sites. Can. J. Soil Sci. 94:317-336

Congreves K A, Voroney R P and Van Eerd L L (2014b) Amending soil with used cooking oil to reduce nitrogen losses after cole crop harvest: a ${ }^{15} \mathrm{~N}$ study. Nutr. Cycl. Agroecosyst. $100: 257-271$

Congreves K A, Hayes A, Verhallen A and Van Eerd L L (2015a) Long-term impact of tillage and crop rotation on soil health at four temperate agroecosystems. Soil Tillage Res. 152:1728

Congreves K A, Grant B B, Campbell C A, Smith W N, VandenBygaart A J, Kröbel R, Lemke R L and Desjardins R L (2015b) Measuring and modelling the long-term impact of crop management on soil C sequestration in the semiarid Canadian prairies. Agron. J. 107:11411154

Constantin J, Mary B, Laurent F, Aubrion G, Fontaine A, Kerveillant P and Beaudoin N (2010) Effects of catch crops, no till and reduced nitrogen fertilization on nitrogen leaching and balance in three long-term experiments. Agricult. Ecosyst. Environ. 135:268-278

Culley J L B (1993) Density and compressibility. In Soil Sampling and Methods of Analysis Ed. M R Carter. pp. 541-557. Lewis, Boca Raton.

Deen W and Kataki P K (2003) Carbon sequestration in a long-term conventional versus conservation tillage experiment. Soil Tillage Res. 74:143-150 
Diochon, A, Gregorich E G, Kellman L, Morrison M and Ma B-L (2016) Greater soil C inputs accelerate loss of C in cropping systems with low N input. Plant Soil 400:93-105

Drinkwater L E, Wagoner P and Sarrantonio M (1998) Legume-based cropping systems have reduced carbon and nitrogen losses. Nature 396:262-265

Ellert B H and Bettany J R (1995) Calculation of organic matter and nutrients stored in soils under contrasting management regimes. Can. J. Soil Sci. 75:529-538

Gál A, Vyn T J, Michéli E, Kladivko E J and McFee W W (2007) Soil carbon and nitrogen accumulation with long-term no-till versus moldboard plowing overestimated with tilledzone sampling depths. Soil Tillage Res. 96: 42-51

Galloway J N, Aber J D, Erisman J W, Seitzinger S P, Howarth R W, Cowling E B and Cosby B J (2003) The nitrogen cascade. Bioscience 53:341-356

Gaudin A C M, Janovicek K, Deen B and Hooker D C (2015a) Wheat improves nitrogen use efficiency of maize and soybean-based cropping systems. Agricult. Ecosyst. Environ. 210:110

Gaudin A C M, Tolhurst T N, Ker A P, Janovicek K, Tortora C, Martin R C and Deen W (2015b) Increasing crop diversity mitigates weather variations and improves yield stability. PLoS ONE 10:e0113261

Glendining M J, Powlson D S, Poulton P R, Bradbury N J, Palazzo D and Li X (1996) The effects of long-term applications of inorganic nitrogen fertilizer on soil nitrogen in the Broadbalk wheat experiment. J. Agricult. Sci. 127:347-363

Gregorich E G, Liang B C, Ellert B H and Drury C F (1996) Fertilization effects on soil organic matter turnover and corn residue C storage. Soil Sci. Soc. Am. J. 60:472-476 
Halpern M T, Whalen J K and Madramootoo C A (2010) Long-term tillage and residue management influences soil carbon and nitrogen dynamics. Soil Sci. Soc. Am. J. 74:12111217

Havlin J L, Kissel D E, Maddux L D, Claassen M M and Long J H (1990) Crop rotation and tillage effects on soil organic carbon and nitrogen. Soil Sci. Soc. Am. J. 54:448-452

Janzen H H, Campbell C A, Izaurralde RC, Ellert B H, Juma N, McGill W B and Zentner R P (1998) Management effects on soil C storage on the Canadian prairies. Soil Tillage Res. 47:181-195

Jenkinson D S, Poulton P R and Bryant C (2008) The turnover of organic carbon in subsoils. Part I. Natural and bomb radiocarbon in soil profiles from the Rothamsted long-term field experiments. Euro. J. Soil Sci. 59:391-399

Kätterer T, Andersson L, Andrén O and Persson J (2008) Long-term impact of land use change on soil carbon stocks on a Swedish farm. Nutr Cycl Agroecosyst 81:145-155

Li C, Frolking S and Frolking T A (1992) A model of nitrous oxide evolution from soil driven by rainfall events: 2. Model applications. J Geophys Res: Atmospheres 97: 9777-9783

Malhi S S and Lemke R (2007) Tillage, crop residue and N fertilizer effects on crop yield, nutrient uptake, soil quality and nitrous oxide gas emissions in a second 4-yr rotation cycle. Soil Tillage Res 96:269-283

R.L. Mulvaney, S.A. Khan, and T.R. Ellsworth 2009. Synthetic Nitrogen Fertilizers Deplete Soil Nitrogen: A Global Dilemma for Sustainable Cereal Production,” Journal of Environmental Quality 2009 38:2295-2314 
Mazzoncini M, Sapkota T B, Ba rberi P, Antichi D and Risaliti R (2011) Long-term effect of tillage, nitrogen fertilization and cover crops on soil organic carbon and total nitrogen content. Soil Tillage Res 114:165-174

McVay K A, Budde JA, Fabrizzi K et al (2006) Management effects on soil physical properties in long-term tillage studies in Kansas. Soil Sci Soc Am J 70:434-438

Neff J C, Townsend A R, Gleixner G, Lehman S J, Turnbull J and Bowman W D (2002) Variable effects of nitrogen additions on the stability and turnover of soil carbon. Nature 419:915-917

Olson K R, Al-Kaisi M M, Lal R and Lowery B (2014) Experimental consideration, treatments, and methods in determining soil organic carbon sequestration rates. Soil Sci Soc Am J 78:78348-360

Pisani O, Frey S D, Simpson A J, Simpson M J (2015) Soil warming and nitrogen deposition alter soil organic matter composition at the molecular-level. Biogeochemistry 123:391-409

Pittelkow C M, Liang X, Linquist B A et al (2015) Productivity limits and potentials of the principles of conservation agriculture. Nature 517:365-368

D.S. Powlson, D.S. Jenkinson, A.E. Johnston, P.R. Poulton, M. J. Glendining, and K.W.T. Goulding. 2010. Comments on "Synthetic Nitrogen Fertilizers Deplete Soil Nitrogen: A Global Dilemma for Sustainable Cereal Production,” J. Environ. Qual. 39:1-4. by R.L. Mulvaney, S.A. Khan, and T.R. Ellsworth in the Journal of Environmental Quality 2009 38:2295-2314.

Rasmussen P E, Allmaras R R, Rohde C R and Roager N C (1980) Crop residue influences on soil carbon and nitrogen in a wheat-fallow system. Soil Sci Soc Am J 44:596-600 
Raun W R and Johnson G V (1999) Improving nitrogen use efficiency for cereal production. Agron J 91:357-363

Riggs C E and Hobbie S E (2016) Mechanisms driving the soil organic matter decomposition response to nitrogen enrichment in grassland soils. Soil Biol Biochem 99:54-65

Rumpel C and Kögel-Knabner I (2011) Deep soil organic matter-a key but poorly understood component of terrestrial C cycle. Plant Soil 338:143-158

Schjønning P, Christensen B T and Carstensen B (1994) Physical and chemical properties of a sandy loam receiving animal manure, mineral fertilizer or no fertilizer for 90 years. Euro J Soil Sci 45:257-268

Simpson A J, Simpson M, Smith E and Kelleher B P (2007) Microbially derived inputs to soil organic matter: are current estimates too low? Environ Sci Technol 41:8070-8076

Smil V (1999) Nitrogen in crop production: An account of global flows. Global Biogeochem Cycles 13:647-662

Stockmann U, Adams MA, Crawford J W et al (2013) The knowns, known unknowns and unknowns of sequestration of soil organic carbon. Agricult Ecosyst Environ 164:80-99

Studdert G A and Echeverria H E (2000) Crop rotations and nitrogen fertilization to manage soil organic carbon dynamics. Soil Sci Soc Am J 64:1496-1503

Van Eerd L L, Congreves K A, Hayes A, Verhallen A and Hooker D C (2014) Long-term tillage and crop rotation effects on soil quality, organic carbon, and total nitrogen. Can J Soil Sci 94:303-315

Varvel G E and Wilhelm W W (2011) No-tillage increases soil profile carbon and nitrogen under long-term rainfed cropping systems. Soil Tillage Res 114:28-36 
West T O and Post W M (2002) Soil organic carbon sequestration rates by tillage and crop rotation. Soil Sci Soc Am J 66:1930-1946

Wright A L, Dou F and Hons F M (2007) Crop species and tillage effects on carbon sequestration in subsurface soil. Soil Sci 172:124-131

Yang X M and Kay B D (2001) Rotation and tillage effects on soil organic carbon sequestration in a typic Hapludalf in Southern Ontario. Soil Tillage Res 59:107-114 


\section{Figure captions}

Fig. 1 Comparison of control $-\mathrm{N}$ to $+\mathrm{N}$ fertilizer $\left(100 \mathrm{~kg} \mathrm{~N} \mathrm{ha}^{-1}\right.$ to corn and $80 \mathrm{~kg} \mathrm{~N} \mathrm{ha}^{-1}$ to wheat) after $11 \mathrm{yrs}$ on mean soil attributes from the $0-120 \mathrm{~cm}$ depth under conventional tillage (left) and no-till (right) systems in three crop rotations. Means with standard error bars that have * indicates significant differences between $\mathrm{N}$ fertilizer treatments $(\mathrm{p}<0.05)$.

Fig. 2 The tillage $\times$ rotation effect $(P=0.0072)$ on change in soil organic $C(S O C)$ content due to $\mathrm{N}$ fertilizer relative to the control (-N) after $11 \mathrm{yrs}$ in the $0-20 \mathrm{~cm}$ depth. Means with standard error bars that have different letters indicate significant differences at $\mathrm{P}<0.05$ across crop rotations. Bars above the line represent SOC gain due to $+\mathrm{N}$ fertilizer $\left(100\right.$ and $80 \mathrm{~kg} \mathrm{~N} \mathrm{ha}^{-1} \mathrm{y}^{-1}$ to corn and wheat, respectively) and * indicates significantly different from control.

Fig. 3 The rotation effect $(\mathrm{P}=0.0059)$ on change in soil total $\mathrm{N}(\mathrm{TN})$ content due to $\mathrm{N}$ fertilizer relative to the control (-N) after $11 \mathrm{yrs}$ in the $0-20 \mathrm{~cm}$ depth. Means with standard error bars that have different letters indicate significant differences at $\mathrm{P}<0.05$ across crop rotations. Bars above the line represent $\mathrm{TN}$ gain due to $+\mathrm{N}$ fertilizer (100 and $80 \mathrm{~kg} \mathrm{~N} \mathrm{ha}^{-1} \mathrm{y}^{-1}$ to corn and wheat, respectively) and $*$ indicates significantly different from control.

Fig. 4 Relationship between the 5-yr (2002-2006) average corn yield or the standard deviation of corn yield and the average soil organic $\mathrm{C}(\mathrm{SOC})$ or total $\mathrm{N}$ content $\left(\mathrm{Mg} \mathrm{ha}^{-1}\right)$ within $5 \mathrm{~cm}$ intervals of the $0-20 \mathrm{~cm}$ depth. ${ }^{\mathrm{ns}}$ denotes a non-significant linear relationship, $*$ denotes a significant linear relationship at $\mathrm{P}<0.05$ 
Table 1 The ANOVA probability values $(\mathrm{Pr}>\mathrm{F})$ for the effects of crop rotation, $\mathrm{N}$ fertilizer, soil depth, and tillage system on soil organic $\mathrm{C}(\mathrm{SOC})$ and total $\mathrm{N}(\mathrm{TN})$ concentrations and contents, $\mathrm{C}: \mathrm{N}$ ratio $(\mathrm{CN})$, and bulk density (BD) in the $0-120 \mathrm{~cm}$ depth after 11 yrs

\begin{tabular}{|c|c|c|c|c|c|c|}
\hline & & & \multirow{3}{*}{\multicolumn{2}{|c|}{$\begin{array}{r}\mathrm{TN} \\
\mathrm{Mg} \mathrm{ha}^{-1} \\
\end{array}$}} & \multirow{3}{*}{$\mathrm{C}: \mathrm{N}$} & \multirow{3}{*}{$\begin{array}{r}\mathrm{BD} \\
\mathrm{g} \mathrm{cm}^{-3} \\
\end{array}$} \\
\hline & SOC & SOC & & & & \\
\hline Effect & $\%$ & $\mathrm{Mg} \mathrm{ha}^{-1}$ & & & & \\
\hline \multicolumn{7}{|l|}{ Conventional tillage } \\
\hline rotation & 0.0299 & 0.2026 & 0.1438 & 0.0994 & 0.2198 & 0.1257 \\
\hline soil depth & $<.0001$ & $<.0001$ & $<.0001$ & $<.0001$ & $<.0001$ & 0.5939 \\
\hline $\mathrm{N}$ fertilizer & 0.0002 & 0.0029 & 0.0022 & 0.0001 & 0.0201 & $<.0001$ \\
\hline depth $\times$ rotation & $<.0001$ & 0.5402 & 0.1833 & 0.4775 & 0.4235 & 0.1967 \\
\hline $\mathrm{N}$ fertilizerxrotation & 0.0004 & 0.4116 & 0.3152 & 0.7569 & 0.4389 & 0.0001 \\
\hline$N$ fertilizer×depth & 0.9483 & 0.7618 & 0.9895 & 0.9694 & 0.7130 & 0.5783 \\
\hline $\mathrm{N}$ fertilizer $\times$ depth $\times$ rotation & 0.0690 & 0.5386 & 1.0000 & 0.9918 & 0.6606 & 0.9386 \\
\hline \multicolumn{7}{|l|}{ No-till } \\
\hline rotation & 0.4638 & 0.532 & 0.8113 & 0.8384 & $<.0001$ & 0.3442 \\
\hline soil depth & $<.0001$ & $<.0001$ & $<.0001$ & $<.0001$ & 0.0025 & $<.0001$ \\
\hline$N$ fertilizer & 0.2834 & 0.9588 & 0.0014 & 0.0028 & 0.012 & 0.109 \\
\hline depth $\times$ rotation & 0.9927 & 0.9788 & 0.7483 & 0.9925 & 1.000 & 0.9212 \\
\hline $\mathrm{N}$ fertilizerxrotation & 0.0342 & 0.3524 & 0.0006 & 0.0006 & 0.0147 & 0.1118 \\
\hline $\mathrm{N}$ fertilizer×depth & 0.8005 & 0.8585 & 0.6216 & 0.8507 & 0.9997 & 0.826 \\
\hline $\mathrm{N}$ fertilizer $\times$ depth $\times$ rotation & 0.7939 & 0.7838 & 0.9539 & 0.9875 & 1.000 & 0.9155 \\
\hline \multicolumn{7}{|l|}{ Conventional and no-till } \\
\hline tillage & 0.1261 & 0.3329 & 0.5639 & 0.2011 & 0.3525 & 0.8096 \\
\hline rotation & 0.0504 & 0.4075 & 0.3257 & 0.1898 & 0.2090 & 0.1039 \\
\hline $\mathrm{N}$ fertilizer & 0.0014 & 0.0684 & $<.0001$ & $<.0001$ & $<.0001$ & $<.0001$ \\
\hline depth & $<.0001$ & $<.0001$ & $<.0001$ & $<.0001$ & $<.0001$ & 0.0004 \\
\hline depth×tillage & $<.0001$ & 0.8758 & 0.0665 & 0.1173 & 0.5975 & 0.1146 \\
\hline tillagexrotation & 0.1133 & 0.9478 & 0.5560 & 0.0019 & 0.7410 & 0.2988 \\
\hline $\mathrm{N}$ fertilizer $\times$ rotation & 0.0172 & 0.9629 & 0.0026 & 0.0081 & 0.1341 & 0.0010 \\
\hline $\mathrm{N}$ fertilizer×depth & 0.7113 & 0.9719 & 0.7079 & 0.9224 & 0.6497 & 0.7769 \\
\hline rotation×depth & 0.0054 & 0.8872 & 0.0971 & 0.9544 & 0.6481 & 0.5280 \\
\hline $\mathrm{N}$ fertilizerxtillage & 0.1205 & 0.0482 & 0.7822 & 0.8686 & 0.4598 & 0.0784 \\
\hline depth×tillagexrotation & 0.4065 & 0.9379 & 0.9668 & 0.9205 & 0.9708 & 0.7292 \\
\hline $\mathrm{N}$ fertilizer×depth×tillage & 0.9629 & 0.6371 & 0.9997 & 0.9592 & 0.9746 & 0.7332 \\
\hline $\mathrm{N}$ fertilizer $\times$ tillagexrotation & 0.0009 & 0.1536 & 0.4336 & 0.0321 & 0.0018 & 0.0121 \\
\hline $\mathrm{N}$ fertilizer $\times$ depth $\times$ tillage $\times$ rotation & 0.4455 & 0.9750 & 0.9999 & 0.9974 & 0.9257 & 0.9819 \\
\hline
\end{tabular}


Table 2 Effect of fertilizer (-N vs $+\mathrm{N})+$ after 11 yrs on soil organic $\mathrm{C}$ and total $\mathrm{N}$ content $\left(\mathrm{Mg} \mathrm{ha}^{-1}\right)$ under conventional and no- tillage systems Soil organic $\mathrm{C}(\mathrm{MgC} \mathrm{ha-1})$

Soil total $\mathrm{N}\left(\mathrm{Mg} \mathrm{N} \mathrm{ha}^{-1}\right)$

\begin{tabular}{|c|c|c|c|c|c|c|c|c|c|c|c|c|c|}
\hline \multirow{2}{*}{$\begin{array}{l}\text { Soil depth } \ddagger \\
\text { (increment) }\end{array}$} & \multicolumn{3}{|c|}{$\mathrm{CC}$} & \multicolumn{2}{|l|}{ C-S-W } & \multicolumn{2}{|l|}{ C-S } & \multicolumn{2}{|l|}{ CC } & \multicolumn{2}{|l|}{ C-S-W } & \multicolumn{2}{|l|}{ C-S } \\
\hline & $\mathrm{n}$ & $-\mathrm{N}$ & $+\mathrm{N}$ & $-N$ & $+\mathrm{N}$ & $-N$ & $+\mathrm{N}$ & $-\mathrm{N}$ & $+\mathrm{N}$ & $-\mathrm{N}$ & $+\mathrm{N}$ & $-\mathrm{N}$ & $+\mathrm{N}$ \\
\hline & \multicolumn{13}{|c|}{ Conventional tillage system } \\
\hline $\begin{array}{l}\text { Average } 0-20 \mathrm{~cm} \\
(5 \mathrm{~cm})\end{array}$ & 12 & $27(2.3)$ & $27(2.3)$ & $34(3.4)$ & $\begin{array}{l}44(3.4) \\
*\end{array}$ & $32(3.2)$ & $29(3.2)$ & $\begin{array}{l}2.7 \\
(0.37)\end{array}$ & $\begin{array}{l}2.8 \\
(0.37)\end{array}$ & $5.0(2.3)$ & $6.6(2.3)$ & $3.3(1.3)$ & $4.8(1.3)$ \\
\hline $\begin{array}{l}\text { Ave. } 20-60 \mathrm{~cm} \\
(10 \mathrm{~cm})\end{array}$ & 12 & $44(6.1)$ & $51(6.1)$ & $57(3.8)$ & $\begin{array}{l}69(3.8) \\
*\end{array}$ & $48(9.7)$ & $58(9.7)$ & $\begin{array}{l}3.9 \\
(0.53)\end{array}$ & $\begin{array}{l}5.2 \\
(0.53)^{*}\end{array}$ & $8.5(1.6)$ & $9.9(1.6)$ & $6.4(2.7)$ & $9.1(2.7)$ \\
\hline $\begin{array}{l}\text { Ave. } 60-120 \mathrm{~cm} \\
(20 \mathrm{~cm})\end{array}$ & 9 & $\begin{array}{l}104 \\
(17.4)\end{array}$ & $\begin{array}{l}122 \\
(17.4) *\end{array}$ & $\begin{array}{l}120 \\
(6.28)\end{array}$ & $\begin{array}{l}116 \\
(5.82)\end{array}$ & $\begin{array}{l}119 \\
(11.7)\end{array}$ & $\begin{array}{l}118 \\
(11.7)\end{array}$ & $6.9(1.0)$ & $\begin{array}{l}9.5(1.0) \\
*\end{array}$ & $8.9(1.9)$ & $10(1.9)$ & $10(1.6)$ & $12(1.6)$ \\
\hline & \multicolumn{13}{|c|}{ No-till system } \\
\hline $\begin{array}{l}\text { Average } 0-20 \mathrm{~cm} \\
(5 \mathrm{~cm})\end{array}$ & 8 & $37(2.3)$ & $36(2.3)$ & $35(1.6)$ & $\begin{array}{l}41(1.6) \\
*\end{array}$ & $31(5.7)$ & $35(5.7)$ & $4.8(1.7)$ & $4.6(1.7)$ & $\begin{array}{l}5.0 \\
(0.80)\end{array}$ & $\begin{array}{l}8.0 \\
(0.80) *\end{array}$ & $\begin{array}{l}5.7 \\
(0.71)\end{array}$ & $\begin{array}{l}6.7 \\
(0.71)\end{array}$ \\
\hline $\begin{array}{l}\text { Ave. } 20-60 \mathrm{~cm} \\
(10 \mathrm{~cm})\end{array}$ & 8 & $77(9.0)$ & $63(9.0)$ & $68(4.5)$ & $62(4.5)$ & $53(6.2)$ & $65(6.2)$ & $11(4.7)$ & $7.7(4.7)$ & $9.3(1.9)$ & $12(1.9)$ & $8.0(1.1)$ & $\begin{array}{l}12(1.1) \\
*\end{array}$ \\
\hline $\begin{array}{l}\text { Ave. } 60-120 \mathrm{~cm} \\
(20 \mathrm{~cm})\end{array}$ & 6 & $\begin{array}{l}131 \\
(4.90)\end{array}$ & $\begin{array}{l}137 \\
(4.90)\end{array}$ & $\begin{array}{l}130 \\
(13.2)\end{array}$ & $\begin{array}{l}127 \\
(13.2)\end{array}$ & $\begin{array}{l}122 \\
(15.4)\end{array}$ & $\begin{array}{l}117 \\
(15.4)\end{array}$ & $12(4.2)$ & $12(4.2)$ & $12(3.2)$ & $\begin{array}{l}17(3.2) \\
*\end{array}$ & $\begin{array}{l}14 \\
(0.97)\end{array}$ & $\begin{array}{l}16 \\
(0.97)\end{array}$ \\
\hline
\end{tabular}

+Treatments had starter fertilizer ( 6 to $12 \mathrm{~kg} \mathrm{~N}$ ha $^{-1}$ ) and in-season $\mathrm{N}$ application of zero $\mathrm{N}$ control (-N) vs. 100 and $80 \mathrm{~kg} \mathrm{~N} \mathrm{ha}^{-1} \mathrm{yr}^{-1}$ to corn and wheat, respectively $(+\mathrm{N})$

¥Soil depths of 0-20, 20-60 and $60-120 \mathrm{~cm}$ correspond to SOC and NT data expressed on an average equivalent mass basis of 598, 1200, and $2780 \mathrm{Mg}$ soil, respectively.

For the mean comparisons, the * asterisk denotes significant differences between fertilizer treatments at $P<0.05$, and standard error in parentheses

CC, continuous corn; C-S-W, corn-soybean-winter wheat rotation; C-S, corn-soybean rotation 
Table 3 The effect of $\mathrm{N}$ fertilizer treatment ${ }^{\dagger}$ on accumulated crop residue $\mathrm{C}$ input ( $\mathrm{Mg} \mathrm{ha}{ }^{-1}$ ) and mean crop yields from 1995-2006, as estimated by the DNDC model $^{\ddagger}$ (Li et al. 1992).

\begin{tabular}{|c|c|c|c|c|c|c|c|c|c|}
\hline \multirow{2}{*}{ Crop Rotation } & \multirow{2}{*}{$\begin{array}{l}\text { Tillage } \\
\text { System }\end{array}$} & \multicolumn{2}{|c|}{$\begin{array}{l}\text { Accumulated C } \\
\text { input }\end{array}$} & \multicolumn{2}{|c|}{ Corn yield } & \multicolumn{2}{|c|}{ Soybeans yield } & \multicolumn{2}{|c|}{ Winter wheat yielc } \\
\hline & & $-\mathrm{N}$ & $+\mathrm{N}$ & $-\mathrm{N}$ & $+\mathrm{N}$ & $-\mathrm{N}$ & $+\mathrm{N}$ & $-\mathrm{N}$ & $+\mathrm{N}$ \\
\hline & & \multicolumn{2}{|c|}{$\mathrm{Mg} \mathrm{C} \mathrm{ha}^{-1}$} & \multicolumn{3}{|c|}{------------------------------- } & $\mathrm{Mg} \mathrm{ha}^{-1} \mathrm{yr}^{-1}$ & --------- & $\begin{array}{ll}---- \\
--1\end{array}$ \\
\hline \multirow[t]{2}{*}{$\begin{array}{l}\text { Continuous } \\
\text { corn }\end{array}$} & No-till & 14.4 & 51.5 & 4.0 & 9.5 & & & & \\
\hline & Conventional & 17.4 & 55.3 & 4.8 & 9.5 & & & & \\
\hline \multirow[t]{2}{*}{$\begin{array}{l}\text { Corn-soybean- } \\
\text { winter wheat }\end{array}$} & No-till & 19.5 & 41.6 & 5.0 & 12 & 2.9 & 2.9 & 2.6 & 5.4 \\
\hline & Conventional & 21.7 & 46.7 & 6.2 & 12 & 2.9 & 2.9 & 3.0 & 5.1 \\
\hline \multirow[t]{2}{*}{ Corn-soybean } & No-till & 28.6 & 53.9 & 5.9 & 8.7 & 3.0 & 3.1 & & \\
\hline & Conventional & 30.9 & 56.5 & 6.6 & 8.7 & 2.8 & 2.9 & & \\
\hline
\end{tabular}

†Treatments had starter fertilizer ( 6 to $12 \mathrm{~kg} \mathrm{~N} \mathrm{ha}^{-1}$ ) and in-season $\mathrm{N}$ application of zero $\mathrm{N}$ control (-N) vs. 100 and $80 \mathrm{~kg} \mathrm{~N}^{-1} \mathrm{yr}^{-1}$ to corn and wheat, respectively $(+\mathrm{N})$

${ }^{\ddagger}$ Simulated using the DNDC model which had an overall average relative error of $5.5 \%$ compared to mean crop yields. 
Table 4 The ANOVA probability values ( $\mathrm{Pr}>\mathrm{F}$ ) for the effect of crop rotation, tillage system, and soil depth ( $5 \mathrm{~cm}$ increments to $20 \mathrm{~cm}$ range) on the percentage change of soil organic carbon (SOC) and total $\mathrm{N}(\mathrm{TN})$ content $\left(\mathrm{Mg} \mathrm{ha}^{-1}\right)$ in the $+\mathrm{N}$ fertilized compared to control treatment ${ }^{+}(-\mathrm{N})$

\begin{tabular}{|c|c|c|}
\hline & Change in SOC & Change in $\mathrm{TN}$ \\
\hline rotation & 0.0062 & 0.0059 \\
\hline tillage & 0.7804 & 0.6380 \\
\hline depth & 0.9618 & 0.9122 \\
\hline rotation $\times$ tillage & 0.0072 & 0.1084 \\
\hline rotation $\times$ depth & 0.9950 & 0.9988 \\
\hline tillagexdepth & 0.9998 & 0.9683 \\
\hline rotation $\times$ tillage $\times$ depth & 0.9995 & 0.9979 \\
\hline
\end{tabular}

†Treatments had starter fertilizer (6 to $12 \mathrm{~kg} \mathrm{~N} \mathrm{ha}^{-1}$ ) and in-season $\mathrm{N}$ application of zero $\mathrm{N}$ control (-N) vs. 100 and $80 \mathrm{~kg} \mathrm{~N} \mathrm{ha}^{-1} \mathrm{yr}^{-1}$ to corn and wheat, respectively $(+\mathrm{N})$ 

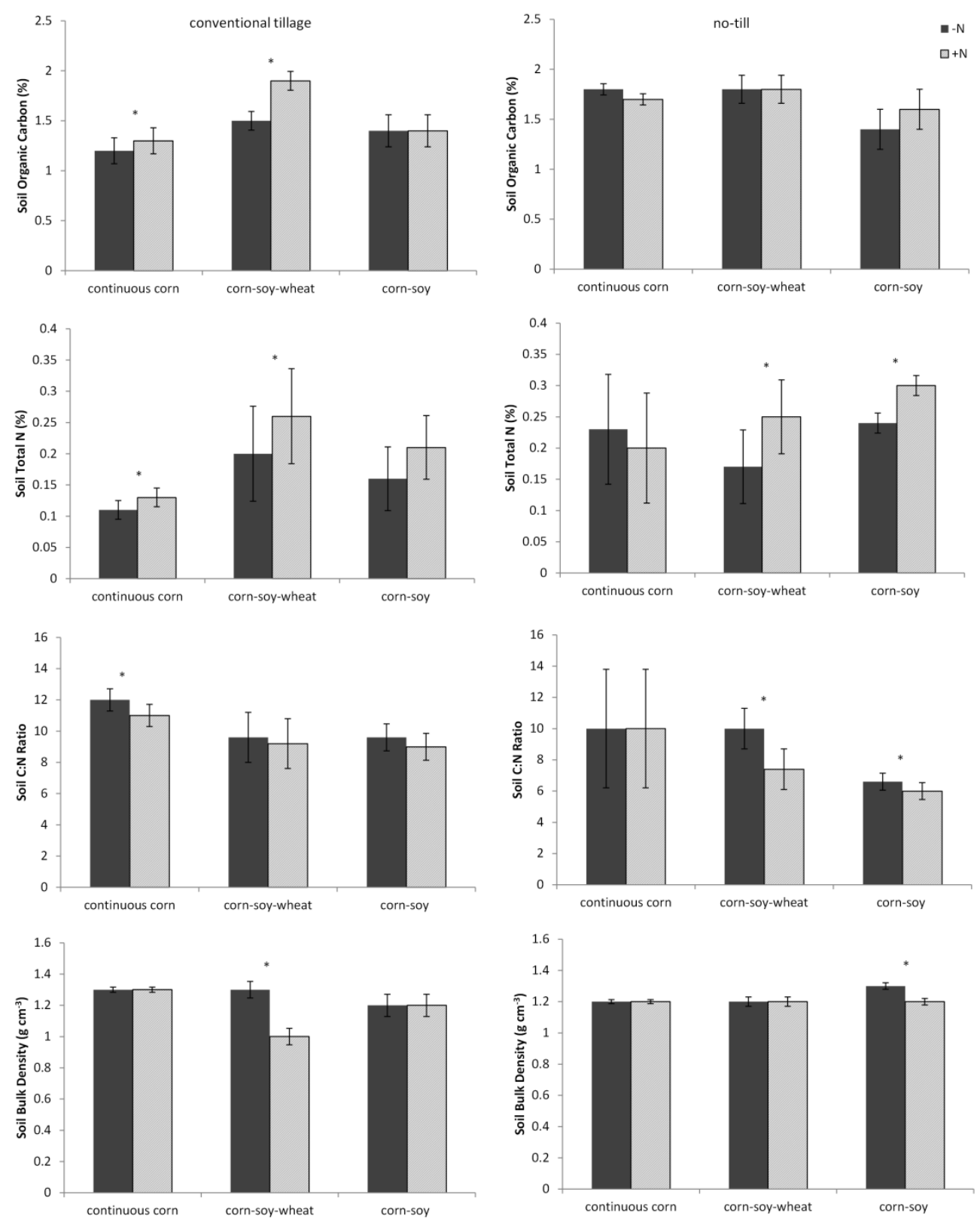

Fig 1 


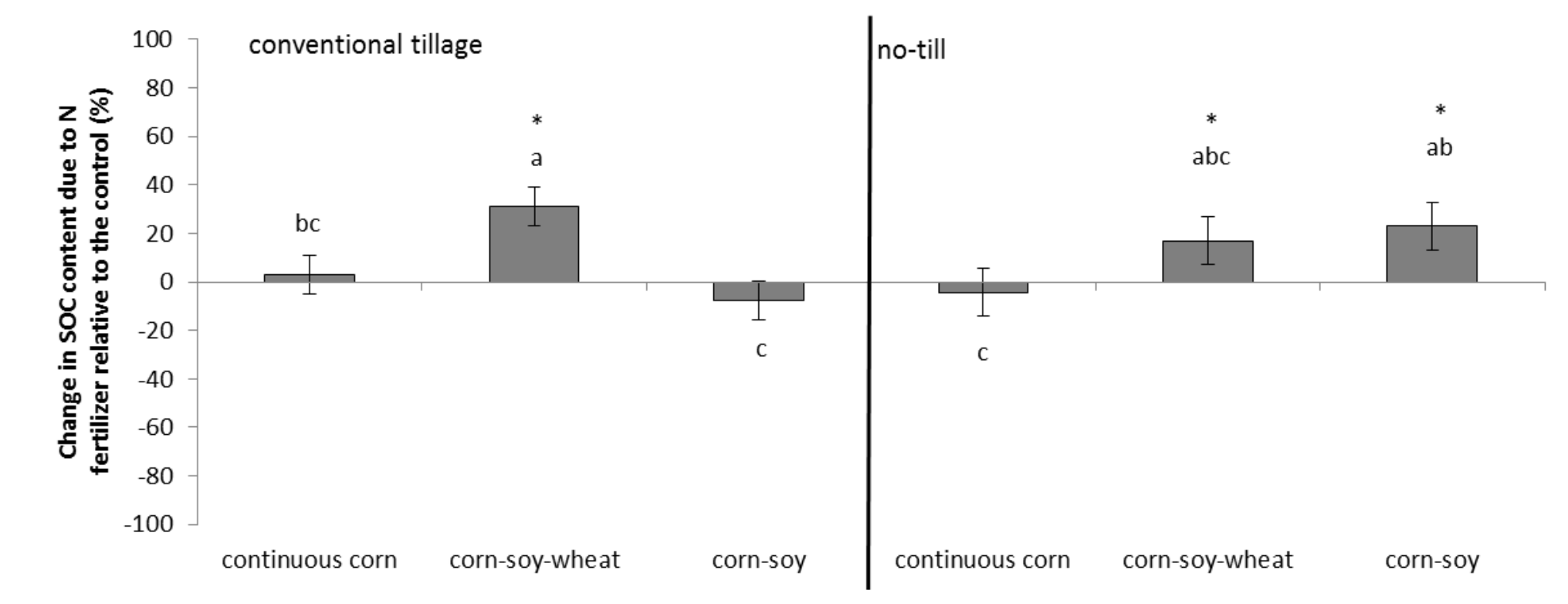

Crop Rotation

Fig 2 


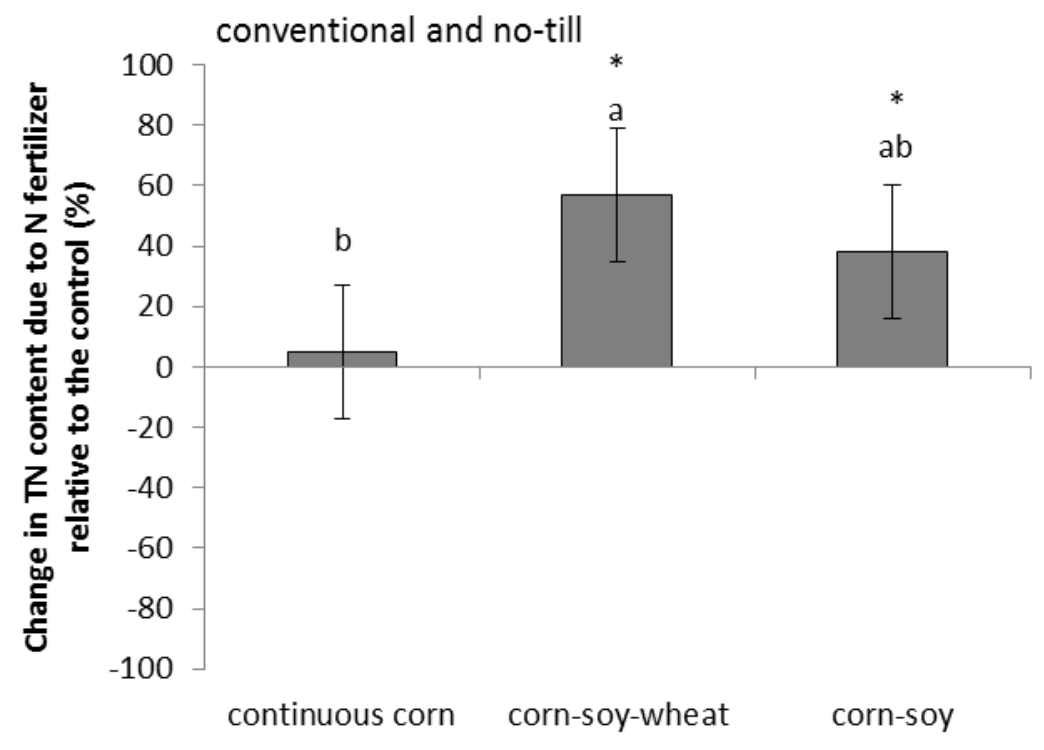

Crop Rotation

Fig 3 

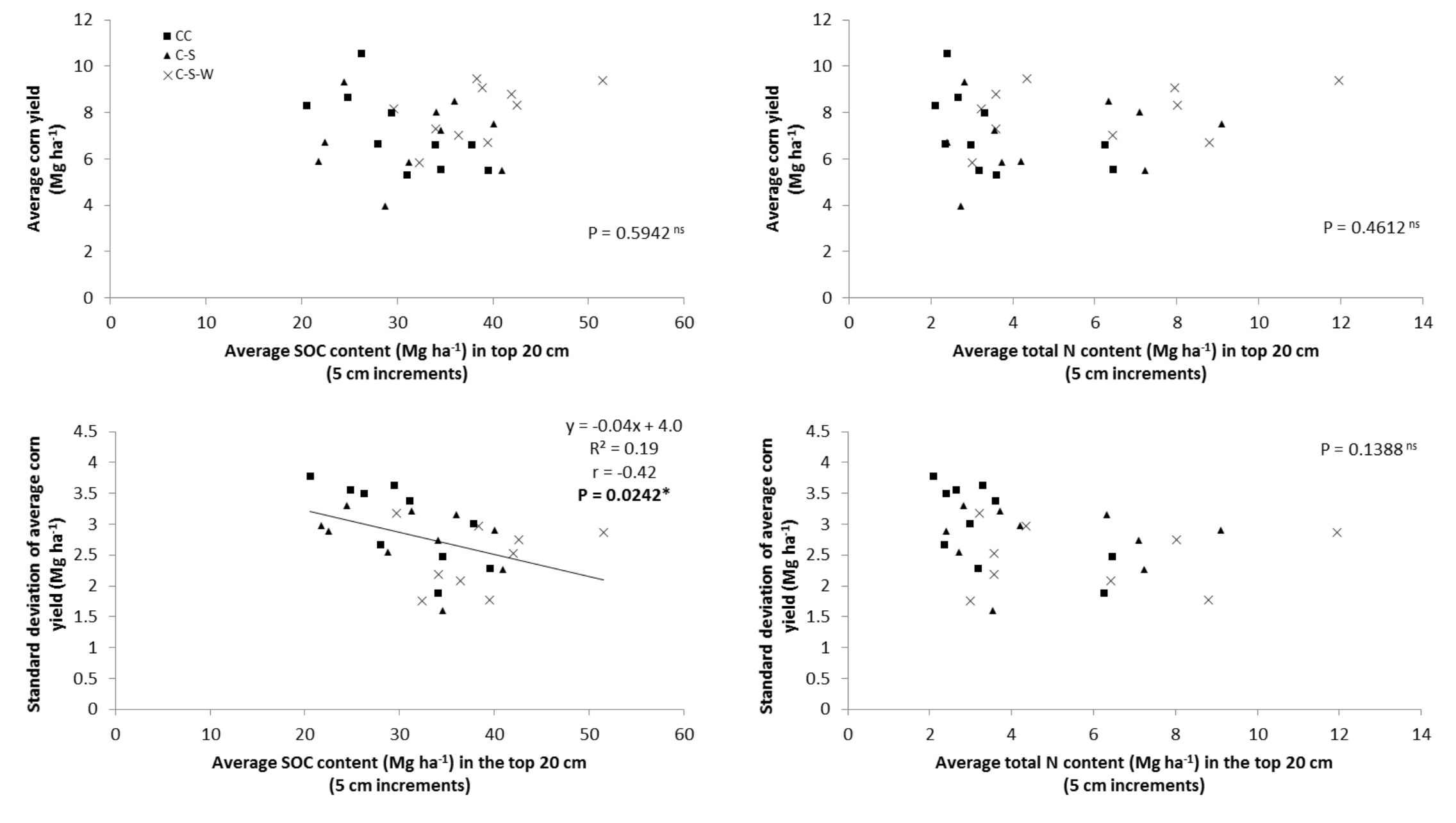

Fig 4 